\title{
THE MANAGEMENT OF PATIENTS WITH SPINAL CORD INJURY BY A HOSPITAL-BASED HOME CARE PROGRAMME
}

\author{
By Franz U. Steinberg, M.D. \\ Department of Rehabilitation Medicine, The Fewish Hospital of St Louis \\ Associate Professor, Washington University School of Medicine
}

THE patient with spinal cord injury who returns to the community must adopt a new life style. Much of his time and effort must be devoted to painstakingly carrying out the many procedures which he has learned in his rehabilitation programme. His future well-being depends on his ability and willingness to practise what he was taught. For the care of the more severely disabled quadriplegic patient, members of the family must be enlisted to assist with routine procedures day in and day out. However, patients and families often find it difficult to transfer what they have learned in the hospital to the home environment. The surroundings and furnishings are different, many of the conveniences provided by the hospital are missing, and absent is the security of knowing that professional personnel are immediately available should help be needed. As a result, procedures are often carried out incorrectly, unsafely and with an undue expenditure of time and energy. All too often patient and family become so wrapped up in the dayto-day care that previous plans to return to school or to work are shelved.

The transition from hospital to home can be made easier and more successful if home health services can be made available, temporarily for some patients and indefinitely for more severely disabled individuals. This report deals with the role of a hospital-based home care programme in the management of paraplegic and quadriplegic patients after discharge from the hospital.

In the United States most home health services are provided by independent agencies. Only about eight per cent of the 2000 certified home health agencies are administered by hospitals (Ryder et al., I969). To the seriously ill and disabled patient, however, the hospital-based home care programme offers definite advantages. The home care staff can become thoroughly acquainted with the patient before he is discharged. Should he be readmitted at a later date, the home care personnel can follow his progress while in the hospital so they will be familiar with his current problems when he returns home. For the spinal cord injured patient with his multiple and complex problems the continuity of care provided by a hospital-based home care division is invaluable (Steinberg et al., I968; Gersten et al., 1968).

The Jewish Hospital of St. Louis has operated a home care programme since 1953. Administratively it is part of the Department of Rehabilitation Medicine but it provides services to patients discharged from any of the hospital departments. It is headed by a part-time internist as the medical director. It provides nursing, social service, physical and occupational therapy and home health aides. A laboratory technician visits at home to draw blood or do electrocardiograms. The patient remains under the care of his own physician. Patients who have no private physician are under the care of one of three part-time salaried internists who visits him at home or sees him in the hospital's outpatient department. One part- 
time salaried surgeon handles minor surgical problems at the patient's home whenever possible.

Patients can contact their physician through the home care office during the day and through the hospital switchboard any time at night or on holidays. If they need to be hospitalised they receive preference for any available bed. The activities of the home care staff are coordinated by bi-weekly staff conferences chaired by the medical director.

Patients are admitted to home care upon application of their physician, who must be a member of the Jewish Hospital staff. The suitability for management at home is evaluated by the medical director and the social worker. The present case load is close to roo patients.

Since 1965,249 patients with spinal cord lesions were admitted to the Department of Rehabilitation Medicine. Thirty-one of these, or I 2 per cent, have been managed by the Home Care Division at one time or another. This percentage is small. However, most patients when discharged from a rehabilitation programme are independent and mobile and they need no follow-up through home care. Other patients who might have benefited from home care live outside of the geographic area of the Home Care Division which covers St. Louis City and County. These are often referred to their local visiting nurse agency.

Most of the spinal cord patients on home care have no private physician and therefore they were assigned to one of the division's physicians for ongoing care. All patients are visited by the nurse from twice a week to once every two weeks. If the patient has an indwelling catheter the nurse changes it and supervises irrigation techniques. She gives general nursing care with emphasis on skin care. Her careful attention to all areas of the skin and her concern about even minor signs of irritation serve as a continuous reminder to patient and family on the importance of meticulous skin care. The nurse makes certain that medications are taken as prescribed and that adequate supplies are on hand. She reports all changes to the physician.

Home health aides are sent to the home if the patient and family require frequent help with simple nursing procedures such as baths, enemas, etc. The aide is supervised by the nurse. If the patient is so severely disabled that he cannot be left alone the aide stays with him for one or two one-half days a week in order to relieve the responsible family member.

The social worker meets and works with patient and family before discharge from the hospital. She visits at home periodically. She tries to allay fears and smooth tensions which may threaten the success of the home programme. She is familiar with the family's resources and assists with applications to welfare and other public agencies. If the patient had left the hospital with tentative plans to return to work or to school she sees to it that these plans are brought to fruition. All too often hospital discharged patients slip into an invalid role. The social worker helps him to look past his immediate situation towards a productive life.

The physical therapist evaluates the physical environment of the home and suggests adaptations in order to ease the care and enhance self-sufficiency. She gives a maintenance exercise programme and teaches patient and family how to exercise on their own in between her visits. She adapts transfer techniques to the home situation and furnishings and she continues gait training if indicated. Physical therapy visits are discontinued if patient and family can carry on independently. 
The occupational therapist is concerned with training the patient in self care, adapting techniques learned in the hospital to the home. She trains the patient in the use of adaptive devices. She directs the patient in activities designed to improve his coordination and endurance or to stimulate vocational interests.

Patients are hospitalised when their condition appears to deteriorate. They are usually admitted to the hospital when they develop a decubitus ulcer which does not heal promptly. Decubitus ulcer care at home has not been satisfactory. Each patient is brought back to the hospital at least once a year for a thorough review including intravenous pyelograms.

Most of the 3I patients admitted to home care were severely disabled, either by the character of the primary lesion or by complications. The patients usually retained the level of independence which they had achieved by the time they were discharged from the hospital. Except for those who continued to recover neurologic function, no significant gains were made nor were functions lost. Some patients who were discharged with imperfectly functioning automatic bladders were converted to continuous catheter drainage, either because incontinence in between bladder expressions had become intolerable or because a hydronephrosis had developed. Most patients continued to use the adaptive equipment which had been furnished them while in the hospital. The most frequent exception was flexor hinge splints which were often discarded as too cumbersome.

Since home care selects patients who are severely disabled or have complications, rehospitalisations are frequent. The 3I patients on home care had I79 hospital admissions or 5.8 admissions per patient. In spinal cord patients the development of decubitus ulcers may be taken as evidence of inadequate care. Of the 3I patients, I I were admitted to the hospital at one time or another for the treatment of decubitus ulcers. Several of the I I patients had multiple admissions for the same complication. It is more meaningful to relate the number of days spent in the hospital to the total number of days on home care. Eighteen patients who were on home care for more than one year spent from 0.8 to 27.4 per cent of their home care days in the hospital, excluding the original admission. Patients with decubitus ulcers had more hospital readmission days than patients who were readmitted for other less easily preventable complications. However, the difference is not significant.

Decubitus ulcers on home care have become less common in recent years. Increased awareness of this complication, better nursing supervision and the use of gel cushions have reduced the incidence.

\section{TABLE I}

Reasons for discharge from home care

$\begin{array}{lr}\text { No longer needed } & 8 \\ \text { Family could no longer provide care } & 4 \\ \text { Uncooperative } & 3 \\ \text { Death } & 6 \\ \text { Total } & 2 \text { I }\end{array}$

Of the 3 I patients, 2 I have been discharged and Io are still on the programme. The reasons for discharge are listed in Table I. Of the four patients who were discharged to long-term care institutions, two have died. Three patients were 
TABLE II

\begin{tabular}{|c|c|c|c|c|c|c|c|}
\hline Name & $\begin{array}{l}\text { Age } \\
\text { Sex }\end{array}$ & Lesion & $\begin{array}{l}\text { Days on } \\
\text { Home Care }\end{array}$ & Services & $\begin{array}{c}\text { No. of } \\
\text { Hospital } \\
\text { Admissions }\end{array}$ & $\begin{array}{l}\text { Hospital } \\
\text { Days }\end{array}$ & $\begin{array}{l}\text { Reasons for } \\
\text { Hospitalisation }\end{array}$ \\
\hline H. B. & $\stackrel{77}{\mathrm{~F}}$ & $\begin{array}{l}\text { Para. } \\
\text { Blind } \\
\text { Deaf }\end{array}$ & 1905 & $\begin{array}{l}\text { Nurse } \\
\text { Aide }\end{array}$ & 3 & 75 & $\begin{array}{l}\text { Decubitus } \\
\text { Bladder distention } \\
\text { Gall bladder disease }\end{array}$ \\
\hline D. B. & $\stackrel{62}{\mathrm{~F}}$ & $\begin{array}{l}\text { Para. } \\
\text { Hip } \\
\text { disartic. }\end{array}$ & 3453 & $\begin{array}{l}\text { Nurse } \\
\text { Housekeeper }\end{array}$ & I9 & 423 & $\begin{array}{l}\text { Decubitus } \\
\text { Hip disartic. } \\
\text { Ur. tract infection } \\
\text { Evaluation }\end{array}$ \\
\hline V. C. & $\begin{array}{l}55 \\
M\end{array}$ & $\begin{array}{l}\text { Quad. } \\
\text { (20 yrs.) }\end{array}$ & $37 \mathrm{I}$ & $\begin{array}{l}\text { Nurse } \\
\text { Aide }\end{array}$ & I & 6 & \\
\hline H. D. & $\begin{array}{l}19 \\
M\end{array}$ & Quad. & 335 & Nurse & 0 & 0 & \\
\hline J. B. & $\begin{array}{l}65 \\
M\end{array}$ & $\begin{array}{l}\text { Quad. } \\
\text { Central } \\
\text { cord } \\
\text { lesion }\end{array}$ & I9I4 & $\begin{array}{l}\text { Nurse } \\
\text { Aide } \\
\text { P.T. } \\
\text { O.T. }\end{array}$ & 7 & 217 & $\begin{array}{l}\text { Ur. tract infections } \\
\text { Calculi } \\
\text { Spasticity } \\
\text { Re-evaluation }\end{array}$ \\
\hline G. L. & $\begin{array}{l}\mathrm{I} 7 \\
\mathrm{M}\end{array}$ & $\begin{array}{l}\text { Quad. } \\
\text { C5-6 }\end{array}$ & 68 & $\begin{array}{l}\text { Social Worker } \\
\text { P.T. } \\
\text { O.T. } \\
\text { Nurse }\end{array}$ & 0 & 0 & \\
\hline E. L. & $\begin{array}{l}20 \\
M\end{array}$ & $\begin{array}{l}\text { Quad. } \\
\text { C5-6 } \\
\text { Asthma }\end{array}$ & I37I & $\begin{array}{l}\text { Social Worker } \\
\text { Nurse } \\
\text { P.T. } \\
\text { Social Worker }\end{array}$ & 3 & 48 & $\begin{array}{l}\text { Decubitus } \\
\text { Ur. tract infection }\end{array}$ \\
\hline D. $\mathrm{McB}$. & $\begin{array}{l}\text { I5 } \\
\text { M }\end{array}$ & Quad. & 452 & $\begin{array}{l}\text { Nurse } \\
\text { P.T. } \\
\text { O.T. }\end{array}$ & I & 39 & $\begin{array}{l}\text { Ur. tract infection } \\
\text { Stone }\end{array}$ \\
\hline V. T. & $\stackrel{60}{\mathrm{~F}}$ & Quad. & 62 & $\begin{array}{l}\text { Social Worker } \\
\text { Nurse }\end{array}$ & 0 & 0 & \\
\hline R. W. & $\begin{array}{l}\text { I9 } \\
M\end{array}$ & $\begin{array}{l}\text { Quad. } \\
\text { Ileal } \\
\text { Bladder }\end{array}$ & 2772 & $\begin{array}{l}\text { P.T. } \\
\text { O.T. } \\
\text { Social Worker }\end{array}$ & 15 & 486 & Calculi \\
\hline
\end{tabular}


discharged because the family was unwilling or unable to carry out even the simplest instructions. The home care staff felt that they could be no longer responsible under these circumstances.

Table II gives a summary of the ten patients presently on home care. Two patients (G. L. and V. T.) have made excellent adjustments and will soon be discharged. The remaining eight patients are severely disabled and will remain on the programme indefinitely.

\section{CONCLUSIONS}

It is not possible to quantitatively measure the benefits of home care. The $3 \mathrm{I}$ patients on home care differ too much from the other 218 spinal cord patients observed during the same period of time to allow valid comparisons. However, some general conclusions can be drawn.

Two types of spinal cord patients benefit from an organised home care programme:

(i) Patients who need home care for a limited period of time to ease the transition from the hospital to living at home. For this group home care is requested if it becomes apparent that patient and family are extremely apprehensive or if they fail to show the initiative necessary to adapt the home to the needs of a spinal cord patient.

(ii) Patients who are so severely disabled that professional help at home will be needed indefinitely. Most of our patients fall into this second category.

Home care does not relieve patient or family of their primary responsibilities. It enables them to accept these responsibilities by providing support and the security of knowing that help and advice are available at any time. Many of our quadriplegic patients would not have been accepted by their families had it not been for the back-up of home care.

The quality of care is improved due to the supervision by the home care staff. Minor problems are handled at home, and there are fewer trips to the hospital emergency room. On the other hand, home care personnel will detect changes to the worse earlier and cause the institution of appropriate measures. Complications are recognised before they become major. Patients are hospitalised more promptly but for briefer periods. In this regard the hospital-based home care programme has definite advantages over the independent home health service.

Socially, home care helps to keep families intact for indefinite periods of time. Only four of our 3I patients needed to be admitted to custodial institutions. Many of our patients have been managed at home for years, one for more than ten years.

\section{REFERENCES}

RYder, C. F., Stitt, P. G. \& Elkin, W. F. (I969). Home health services, past, present and future. Am. F. Public Health, 59, I720.

Steinberg, F. U., Birenbaum, A. \& STOdDARD, E. A. (1968). Management at home of patients severely disabled by spinal cord lesions. Arch. Phys. Med. 49, 592.

Gersten, J. W., Miller, B., Cenkovich, F. \& Dinken, H. (i968). Comparison of home and clinic rehabilitation for chronically ill and physically disabled patients. Arch. Phys. Med. 49, 615. 